\title{
Employee Satisfaction Survey in Function of Business Improvement
}

UDC: 005.35 .330 .101 .32

$005.95 / .96$

DOI: 10.7595/management.fon.2015.0021

Encouraging work performance is a strategic and key task, reflected in employees' motivation and creating conditions to express their creativity, as well as an adequate way of evaluating and rewarding work results. In the context of improving efficiency, an important precondition is continuous research and measuring employee satisfaction. The results of this research are directed primarily at desgning processes and activities, as well as defining short-term and long-term measures to improve satisfaction and motivation. This paper will analyze data on employee satisfaction, obtained by interviewing employees at the Faculty of Agriculture in Zemun. The purpose of this study is to identify the causes of employees' job satisfaction/dissatisfaction, in order to take measures to improve employee satisfaction and to help improve business performance.

Keywords: employee satisfaction, motivation, business improvement, Faculty of Agriculture

\section{Introduction}

The aspiration of every man is to achieve economic stability, independence, identity, but also a free development of his personality, creativity, status and prestige in the society through the work he does. Employees want to develop through business and achieve as individuals, to use and develop their talents and skills to achieve work results and successes that will be recognized (Davis, 1992). Job satisfaction is a combination of internal and external factors. Internal factors include the nature of the work one performs, business tasks, professional development, responsibility and achievements in business. External factors include environmental conditions, such as wages, staff and managers. Internal factors enhance satisfaction; on the other hand, external ones prevent dissatisfaction (Sousa-Poza, 2000). The most important determinants of job satisfaction are interesting and creative work, good working relationships with managers and colleagues, high salaries, autonomy in workplace and career prospects, as well as job security and the ability to create a balance between work and private life (Locke, 1976). On the other hand, job dissatisfaction affects employees' health, particularly mental health, causes depression and anxiety, while the correlation with physical health is more modest (Faragher et al., 2005). There are numerous factors that affect both the satisfaction of employees and their dissatisfaction (Figure 1). 


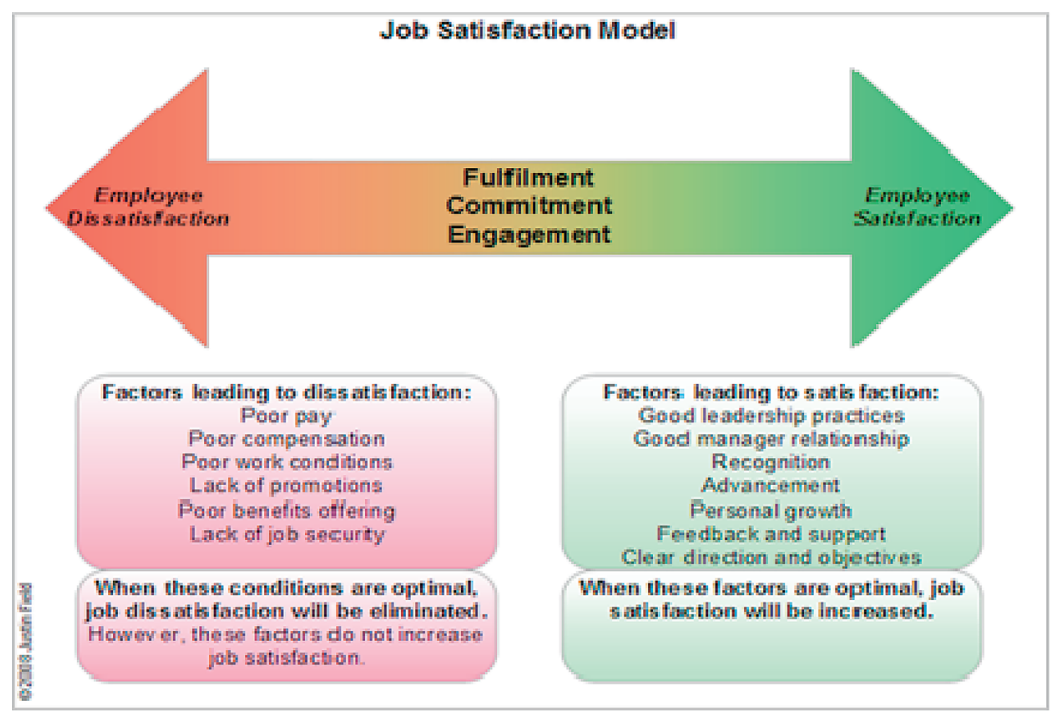

Source:Field, J., 2008.

Figure 1: Job satisfaction model

Motivated employees are an important component to a successful company. These are employees who enjoy their work, to whom work gives great satisfaction, whereby the influencing factors on satisfaction are career opportunities and career development, teamwork and challenging opportunities (Furnham, 1997). Motivation and employee satisfaction are becoming the basis of modern human resource management, because only the quality motivational system can help organizations to increase their competitive ability and value (Early et al., 2011).Numerous motivation programmes that promote performance and employee satisfaction are developed in recent years. Examples of new motivational programs indicate that employees, their motivation, development and satisfaction become the centre of management thinking, because they represent the main tool of competitive ability and market advantage. Managers must use both organizational and psychological knowledge to build a quality motivational content and combine those motivational techniques that match the specific situation, in order to create a favorable organizational climate and the conditions in which employees can satisfy their own needs and desires, and thus give maximum contribution the company's success. Stimulation encourages staff to creativity, better results, greater responsibility and obligations. The combination of material and moral forms of stimulation is achieved by full engagement of employees at work, and reflects on the rationality of the decision-making process, economy and efficiency (Prvulović et al., 2009).

A large number of researchers studied the methodologies concerning job satisfaction. There are various factors that have an impact on job satisfaction at the faculty in higher education. Different researchers have conducted studies and have come up with various parameters. These variables do not differ much in different countries. Some predictors that were studied are: Facility at workplace (Viswesvaran et al.,1998); relations with co-workers and work environment (Luthans,2005; Oshagbemi, 2003); Pay (Khalidet al., 2012;Kusku, 2003; Chen et al., 2006); Promotion (Petersonetal.,2003; SsegangaandGarrett, 2005) and Equitable work load (Shahzadetal.,2010; Chenetal., 2006)

Therefore, the aim of this paper is to point out the areas of satisfaction and dissatisfaction of employees at the Faculty of Agriculture, University of Belgrade, in order to reach conclusions about their causes, as well as possibilities for taking actions, primarily aimed at improving employee satisfaction.

\section{Materials and methods}

In order to determine employee satisfaction at the Faculty of Agriculture in Zemun anonymous poll using written questionnaire was carried out. In preparing the questionnaire the literature in the field of human resource management was reviewed. (Dessler, 2007., Maslow, 2004., Mihailović, 2002.). 
Using a questionnaire on employee satisfaction in the workplace, demographic data were first defined (gender of employees, age, activity of employees and years of service), as well as data on the respondents' opinions about the factors that influence their satisfaction in the workplace. The survey contains 31 questions: one question is open, 6 are closed questions where two questions are the binomial, and the other four are multiple choice, while the remaining 24 issues make Likert type scales. The scale consists of 24 statements about different aspects of job satisfaction, and the answers are defined on a five-point scale: 1 - very dissatisfied, 2 - dissatisfied, 3 - neither satisfied nor dissatisfied, 4 - satisfied, 5 - very satisfied.

Data processing was performed using the SPSS software package. In addition to indicators of descriptive statistics (, S, Mo, Me, Cv), adequate graphs were used to display demographic indicators. Mann-Whitney U-test and Kruskal-Wallis test were used to determine whether there is a difference in employees' attitudes on individual issues of job satisfaction. The paper also used the factor analysis to obtain a number of latent variables (factors) of the initial number of indicators that explain the existing interdependence and enable a clearer understanding of the results.

\section{Research results}

Employee survey at the Faculty of Agriculture was conducted in March 2015, and participation was voluntary and anonymous. There was no personal data in the questionnaire that would enable the identification of individuals, ie., all conditions for respondents' anonymity were provided. The survey was completed by 129 of a total of 523 employees (about $25 \%$ of employees), and 12 surveys were not processed as they lacked a certain demographic data.

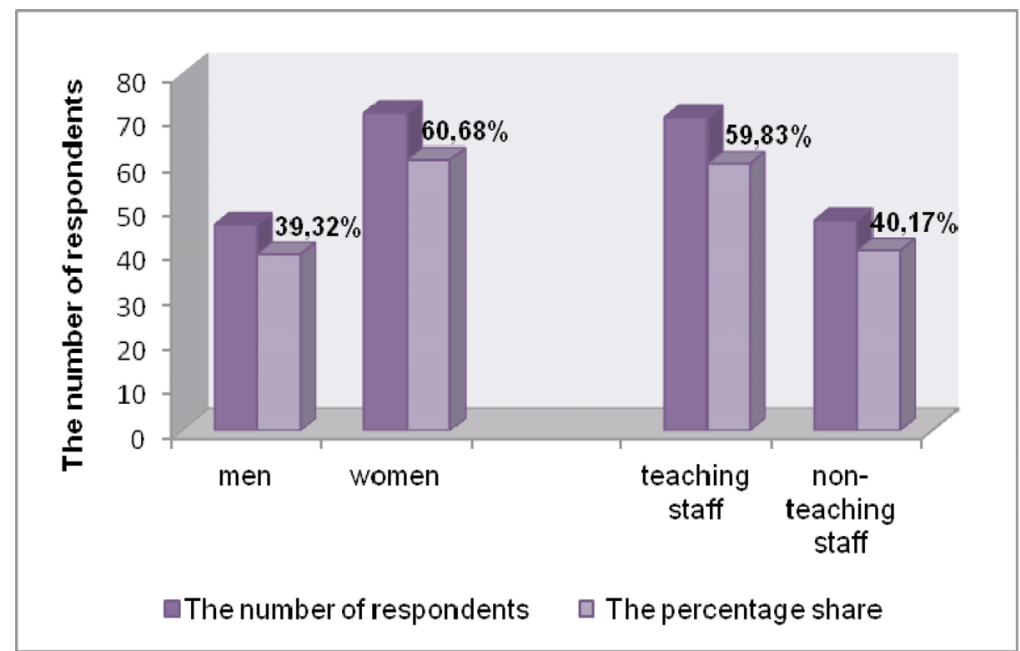

Source: Authors' calculation based on questionnaire survey data

Figure 2: Survey Respondents by gender and busines activity

There were 46 men and 71 women who responded to the survey, i.e., 70 employees working as teaching staff and 47 who belonged to non-teaching staff). Employees aged 51-60 years are the most represented, and the number of those who are younger than 30 is the smallest. Regarding education level, employees with a $\mathrm{PhD}$ represent the largest share, and the lowest share are the ones with elementary education (figures:1, 2, 3).

Among the respondents, those with 21-30 years of service are the most represented and the employees who have up to 10 years of service are the least represented (figure 4).The question "whether the work you do is for you: a) only the way to provide material life conditions b) realization of professional inclinations and interests, c) both"; $14 \%$ of respondents decided in favour of the first option, where all but one of the respondent, are the non-teaching staff.Only $8 \%$ of respondents chose the second option, and they are all teaching staff. Most respondents (78\%) believe that work performed means a realization of professional inclinations and interests, as well as providing material life conditions. 


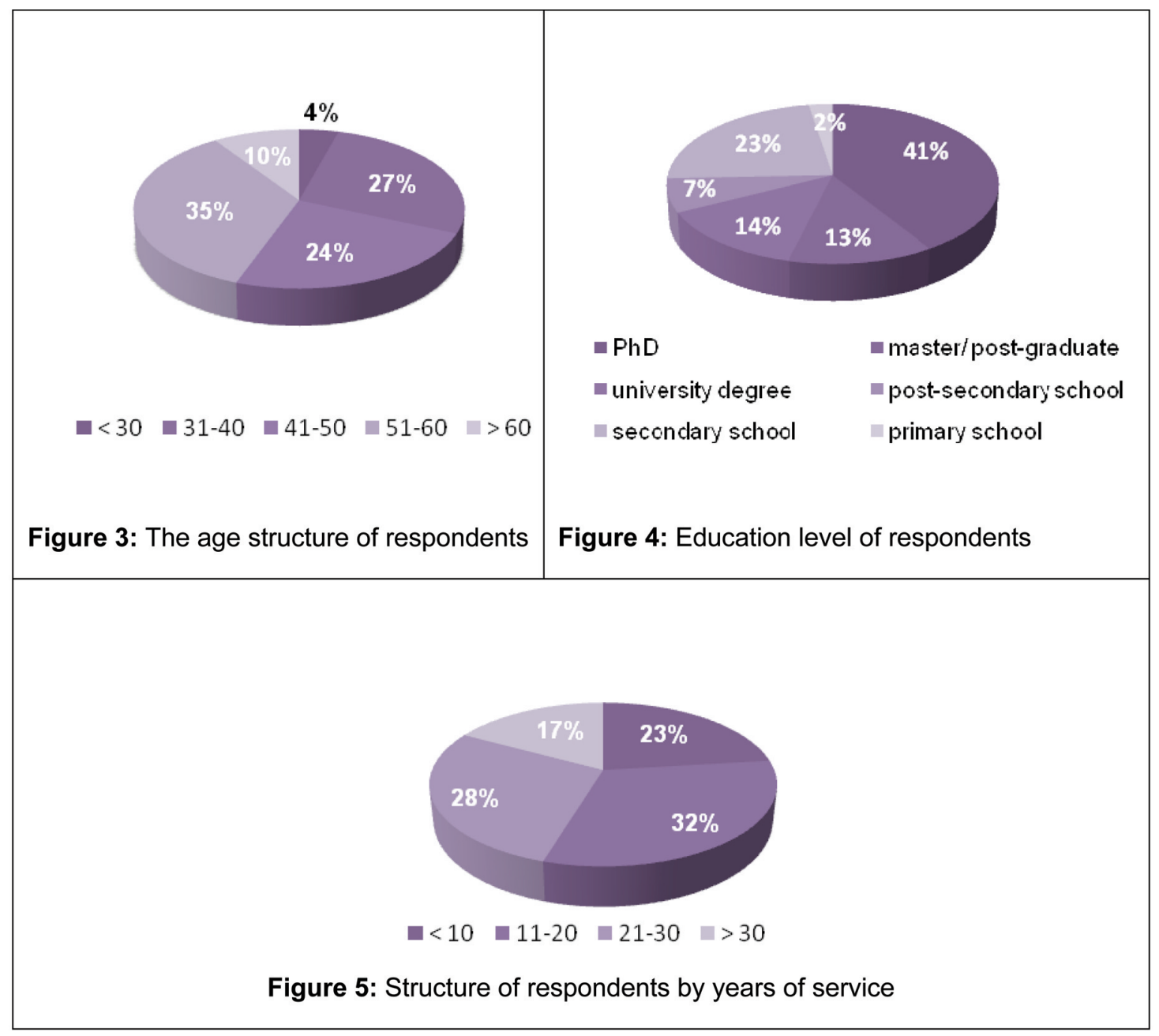

Source: Authors' calculation based on questionnaire survey data

The research results indicate the most important reasons for job satisfaction and job dissatisfaction (Table 1). Employees are most satisfied with working hours $(=4.38)$, so the majority of respondents declared themselves as very satisfied with working hours $\left(\mathrm{M}_{\mathrm{O}}=5\right)$. The lowest variability is also noted in the responses to this question $(\mathrm{S}=0.68 \mathrm{i} \mathrm{Cv}=13.58 \%$ ). Respondents believe that the reward system does not stimulate the commitment and creativity of employees in an adequate way, considering that this question received the lowest average rating $(=2.44)$. 
Table 1: Descriptive statistics

\begin{tabular}{|c|c|c|c|c|c|c|}
\hline & $X_{i}$ & $\bar{X}$ & $\mathrm{M}_{\mathrm{e}}$ & $M_{0}$ & S & $\begin{array}{l}\mathrm{Cv} \\
(\%)\end{array}$ \\
\hline Adequacy of work equipment. & $\mathrm{X}_{1}$ & 2.90 & 3.00 & 3.00 & 1.00 & 33.44 \\
\hline Workplace safety. & $\mathrm{X}_{2}$ & 3.59 & 4.00 & 4.00 & 1.11 & 27.69 \\
\hline Working hours. & $\mathrm{X}_{3}$ & 4.38 & 4.00 & 5.00 & 0.68 & 13.58 \\
\hline The time available to perform given tasks. & $\mathrm{X}_{4}$ & 3.83 & 4.00 & 4.00 & 0.93 & 23.28 \\
\hline $\begin{array}{l}\text { How the reward system stimulates work quality, commitment and } \\
\text { creativity of employees. }\end{array}$ & $X_{5}$ & 2.44 & 3.00 & 3.00 & 1.11 & 37.00 \\
\hline $\begin{array}{l}\text { How your work and commitment are monitored and evaluated } \\
\text { objectively and fairly. }\end{array}$ & $\mathrm{X}_{6}$ & 2.92 & 3.00 & 3.00 & 1.00 & 33.38 \\
\hline Financial compensation for work. & $\mathrm{X}_{7}$ & 2.81 & 3.00 & 3.00 & 1.02 & 33.88 \\
\hline Cooperating with colleagues. & $\mathrm{X}_{8}$ & 3.97 & 4.00 & 4.00 & 0.91 & 22.73 \\
\hline Interpersonal relations. & $\mathrm{X}_{9}$ & 3.22 & 3.00 & 4.00 & 1.06 & 26.49 \\
\hline Superior support. & $\mathrm{X}_{10}$ & 3.54 & 4.00 & 4.00 & 1.11 & 27.76 \\
\hline Communication with your immediate supervisor in everyday work. & $\mathrm{X}_{11}$ & 4.09 & 4.00 & 5.00 & 0.99 & 19.82 \\
\hline Possibility to bring up your ideas to superiors. & $\mathrm{X}_{12}$ & 3.88 & 4.00 & 4.00 & 0.96 & 23.93 \\
\hline $\begin{array}{l}\text { Treating the ideas and suggestions of employees with consideration } \\
\text { and respect. }\end{array}$ & $\mathrm{X}_{13}$ & 3.13 & 3.00 & 4.00 & 1.01 & 25.33 \\
\hline Regular evaluation of your work by managers. & $\mathrm{X}_{14}$ & 3.15 & 3.00 & 3.00 & 0.96 & 31.94 \\
\hline Options that you have for continuing education. & $X_{15}$ & 3.03 & 3.00 & 3.00 & 1.06 & 35.27 \\
\hline Advancement Criteria. & $\mathrm{X}_{16}$ & 3.14 & 3.00 & 3.00 & 1.07 & 35.53 \\
\hline $\begin{array}{l}\text { Appreciation of professional skills and ethical values for } \\
\text { advancement. }\end{array}$ & $\mathrm{X}_{17}$ & 3.04 & 3.00 & 3.00 & 1.00 & 33.45 \\
\hline $\begin{array}{l}\text { Being informed about current issues at the university by the } \\
\text { management. }\end{array}$ & $\mathrm{X}_{18}$ & 3.38 & 4.00 & 4.00 & 1.04 & 26.00 \\
\hline Available information on the financial situation. & $\mathrm{X}_{19}$ & 3.32 & 3.00 & 4.00 & 1.10 & 27.59 \\
\hline I feel emotionally exhausted after work. & $\mathrm{X}_{20}$ & 3.00 & 3.00 & 3.00 & 1.21 & 40.35 \\
\hline I feel physically exhausted after work. & $\mathrm{X}_{21}$ & 3.09 & 3.00 & 3.00 & 1.19 & 39.63 \\
\hline I can feel tiredness just thinking that I should go to work. & $\mathrm{X}_{22}$ & 3.08 & 3.00 & 3.00 & 1.39 & 46.35 \\
\hline Are you afraid that you will lose your job? & $\mathrm{X}_{23}$ & 4.05 & 4.00 & 5.00 & 0.97 & 19.45 \\
\hline $\begin{array}{l}\text { Taking all this into account, rate the satisfaction with the job } \\
\text { performing. }\end{array}$ & $\mathrm{X}_{24}$ & 3.85 & 4.00 & 4.00 & 0.84 & 20.92 \\
\hline
\end{tabular}

Source: Authors' calculation

The factor analysis is used in order to more comprehensively perceive the survey results. This technique allows us to analyze interrelationships among a large number of interrelated variables explaining these relationships in terms of a smaller number of latent variables called factors. Bartlett's test of sphericity (Bartlett, 1954) and Kaiser-Meyer-Olkin (KMO) Measure of Sampling Adequacy (Kais, 1974) were used to verify the feasibility of the factor analysis. The Bartlett's test of sphericity should be significant $(p<0.05)$ for the factor analysis to be considered appropriate, while the KMO index ranges from 0-1, with 0.6 recommended as the minimum value for a good factor analysis (Tabachnick and Fidell, 2007.). The results of these two tests justify and support the use of the factor analysis method (table 2).

Table 2: KMO and Bartlett's test

\begin{tabular}{|l|c|c|}
\hline \multicolumn{2}{|c|}{ Kaiser-Meyer-Olkin Measure of Sampling Adequacy } & 0.817 \\
\hline \multirow{3}{*}{ Bartlett's test of sphericity } & Approx. Chi-Square & 1462.298 \\
\cline { 2 - 3 } & df & 276 \\
\cline { 2 - 3 } & Sig. & 0.000 \\
\hline
\end{tabular}

Source: Authors' calculation based on questionnaire survey data

The factor analysis was conducted using principal components analysis. Based on the determined characteristic equations and Kaiser's criterion ( according to this criterion only the common factors, having characteristic root greater than one should be retained) only 6 factors are considered as essential for further 
analysis. In regard to dispersion distribution per individual factors, it is obvious that most were included in the first factor, over $30 \%$; the second factor included $10.64 \%$, while the proportional share of remaining factors in total variation is increasingly lower (Table 3).

After that, orthogonal rotation of primary factorial solution using Kaiser varimax method was performed. By rotation, a factorial matrix was obtained. Elements of this matrix are factorial weights, and weights of value above 0.5 are considered significant, and based on their correlation with certain factor, a factor interpretation was carried out (Table 3).

The first factor explained $31.37 \%$ of total variability (Table 3 ), and if taking into account connections with the starting five features $\left(X_{8}, X_{9}, X_{10}, X_{11}\right.$ and $\left.X_{12}\right)$, it can be defined as a factor for explaining interpersonal relationships. High factor loadings with other separate factors can be noticed with five variables that relate to opportunities for education and advancement, and it is defined as a factor of development opportunities. The third factor relates to the reward system, given that the variables $X_{5}, X_{6}$ and $X_{7}$ have the highest factorial weights to this factor.The fourth factor is dominated by features related to job exhaustion $\left(X_{20}, X_{21}\right.$ and $\left.X_{22}\right)$. The fifth factor is defined by characteristics that are associated with working conditions, and the sixth factor refers to the employee awareness.

All variables have a high factor loading with only one factor, whereas the variable $X_{24}$ does not connect with any factor. Considering that this is a comprehensive assessment of current job satisfaction which includes all aspects of satisfaction, the result is more than logical.

Table 3: Matrix of factor loadings after factor rotation

\begin{tabular}{|c|c|c|c|c|c|c|}
\hline \multirow{2}{*}{ Indicators } & \multicolumn{6}{|c|}{ Factors } \\
\hline & 1 & 2 & 3 & 4 & 5 & 6 \\
\hline$X_{1}$ & -0.06 & 0.43 & 0.02 & -0.03 & 0.58 & 0.02 \\
\hline $\mathrm{X}_{2}$ & 0.33 & 0.02 & 0.49 & -0.03 & 0.52 & 0.03 \\
\hline$X_{3}$ & 0.27 & -0.01 & 0.07 & 0.09 & 0.72 & 0.23 \\
\hline$X_{4}$ & 0.30 & 0.05 & 0.36 & -0.07 & 0.66 & -0.00 \\
\hline$X_{5}$ & -0.03 & 0.24 & 0.78 & -0.02 & 0.04 & 0.11 \\
\hline $\mathrm{X}_{6}$ & 0.23 & 0.47 & 0.63 & 0.08 & 0.17 & 0.04 \\
\hline$X_{7}$ & -0.09 & 0.37 & 0.60 & 0.00 & 0.27 & 0.31 \\
\hline $\mathrm{X}_{8}$ & 0.52 & 0.09 & 0.15 & 0.08 & 0.06 & -0.57 \\
\hline$X_{9}$ & 0.53 & 0.01 & 0.42 & -0.04 & -0.01 & -0.30 \\
\hline$X_{10}$ & 0.77 & 0.24 & 0.20 & 0.07 & 0.14 & 0.04 \\
\hline$X_{11}$ & 0.85 & 0.14 & -0.04 & 0.07 & 0.10 & 0.07 \\
\hline $\mathrm{X}_{12}$ & 0.76 & 0.27 & -0.01 & 0.11 & 0.19 & 0.17 \\
\hline$X_{13}$ & 0.49 & 0.63 & 0.15 & 0.05 & 0.03 & -0.04 \\
\hline$X_{14}$ & 0.45 & 0.52 & 0.28 & 0.08 & 0.05 & 0.01 \\
\hline$X_{15}$ & 0.06 & 0.77 & 0.04 & -0.02 & 0.18 & 0.16 \\
\hline $\mathrm{X}_{16}$ & 0.16 & 0.73 & 0.26 & 0.05 & 0.11 & 0.10 \\
\hline$X_{17}$ & 0.33 & 0.73 & 0.30 & 0.08 & 0.02 & 0.12 \\
\hline $\mathrm{X}_{18}$ & 0.31 & 0.36 & 0.08 & 0.01 & 0.25 & 0.69 \\
\hline$X_{19}$ & 0.07 & 0.15 & 0.23 & 0.03 & 0.00 & 0.81 \\
\hline$X_{20}$ & 0.08 & -0.01 & -0.07 & 0.91 & 0.11 & 0.02 \\
\hline$X_{21}$ & 0.11 & -0.03 & 0.15 & 0.87 & 0.03 & -0.02 \\
\hline$X_{22}$ & 0.04 & 0.11 & -0.05 & 0.86 & -0.02 & 0.027 \\
\hline$X_{23}$ & -0.15 & 0.16 & -0.04 & 0.31 & 0.50 & -0.23 \\
\hline$X_{24}$ & 0.32 & 0.28 & 0.43 & 0.06 & 0.47 & 0.22 \\
\hline $\begin{array}{c}\% \text { of } \\
\text { variance } \\
\text { explained }\end{array}$ & 31.37 & 10.64 & 8.83 & 6.65 & 5.89 & 4.64 \\
\hline
\end{tabular}

Source: Authors' calculation 
The research was further continued in order to determine whether there are statistically significant differences in employees' attitudes determined by demographic groups. Differences in attitudes, according to gender and business activity were tested by Mann-Whitney $U$ test, and in other cases, the Kruskal-Wallis test was used (age, qualifications and professional seniority). The results of these tests show that the differences in employees' attitudes by separate factors were not statistically significant. There were no significant differences as the average employees' attitudes on all issues are slightly above or slightly below 3 (neither satisfied nor dissatisfied), which confirmed the results of both tests. Working conditions were evaluated with the highest average mark of 3.75 (Table 4), while men are slightly more satisfied than women, persons of over 60 years of age, teaching staff with a doctorate and employees with more than 30 years of service. When it comes to interpersonal relationships, women are slightly more satisfied, followed by employees aged 41-50, teaching staff with master / post-graduate diploma and employees up to 10 years of service. Employee awareness is evaluated with an average mark of 3.35. It can be noticed that employees in the younger age categories feel that they are better informed than the others (younger than 30 years of age, with less than 10 years of service, with master / post-graduate diploma, teaching staff). Regarding development opportunities, employees are neither satisfied nor dissatisfied (average mark of 3.10). The most dissatisfied are employees younger than 30 years, non-teaching staff, particularly those with primary school.

Table 4: Results by separate factors and demographic indicators

\begin{tabular}{|c|c|c|c|c|c|c|c|}
\hline & $\begin{array}{l}\text { Interpersonal } \\
\text { relationships }\end{array}$ & $\begin{array}{l}\text { Development } \\
\text { opportunities }\end{array}$ & $\begin{array}{l}\text { Reward } \\
\text { system }\end{array}$ & $\begin{array}{c}\text { Job } \\
\text { exhaustion }\end{array}$ & $\begin{array}{c}\text { Working } \\
\text { conditions }\end{array}$ & $\begin{array}{l}\text { Employees } \\
\text { awareness }\end{array}$ & Average \\
\hline \multicolumn{8}{|c|}{ gender } \\
\hline male & 3.72 & 3.22 & 2.83 & 3.10 & 3.76 & 3.41 & 3.34 \\
\hline female & 3.75 & 3.02 & 2.66 & 3.03 & 3.74 & 3.30 & 3.25 \\
\hline \multicolumn{8}{|c|}{ age } \\
\hline$<30$ & 3.92 & 2.92 & 2.47 & 3.00 & 3.92 & 3.70 & 3.32 \\
\hline $31-40$ & 3.83 & 3.11 & 2.60 & 2.89 & 3.59 & 3.36 & 3.23 \\
\hline $41-50$ & 4.01 & 3.24 & 3.01 & 3.12 & 3.72 & 3.46 & 3.43 \\
\hline $51-60$ & 3.54 & 3.03 & 2.59 & 3.03 & 3.77 & 3.22 & 3.20 \\
\hline$>60$ & 3.47 & 3.04 & 2.97 & 3.52 & 4.15 & 3.32 & 3.41 \\
\hline \multicolumn{8}{|c|}{ business activity } \\
\hline $\begin{array}{l}\text { teaching } \\
\text { staff }\end{array}$ & 3.77 & 3.30 & 2.83 & 2.94 & 3.84 & 3.61 & 3.38 \\
\hline $\begin{array}{l}\text { non- } \\
\text { teaching } \\
\text { staff }\end{array}$ & 3.70 & 2.79 & 2.57 & 3.23 & 3.62 & 2.96 & 3.14 \\
\hline \multicolumn{8}{|c|}{ professional qualifications } \\
\hline $\begin{array}{l}\text { Primary } \\
\text { school }\end{array}$ & 3.60 & 2.27 & 2.78 & 2.33 & 3.00 & 1.67 & 2.61 \\
\hline $\begin{array}{l}\text { Secondary } \\
\text { school }\end{array}$ & 3.81 & 2.84 & 2.68 & 3.31 & 3.76 & 3.11 & 3.25 \\
\hline $\begin{array}{l}\text { Post- } \\
\text { secondary } \\
\text { school }\end{array}$ & 3.35 & 2.85 & 2.63 & 2.79 & 3.50 & 3.25 & 3.06 \\
\hline $\begin{array}{l}\text { University } \\
\text { degree }\end{array}$ & 3.91 & 3.03 & 2.29 & 3.06 & 3.60 & 2.91 & 3.13 \\
\hline $\begin{array}{l}\text { master/ } \\
\text { post- } \\
\text { graduate }\end{array}$ & 4.00 & 3.21 & 2.76 & 2.80 & 3.68 & 3.47 & 3.32 \\
\hline $\mathrm{PhD}$ & 3.64 & 3.32 & 2.90 & 3.08 & 3.90 & 3.71 & 3.43 \\
\hline \multicolumn{8}{|c|}{ years of service } \\
\hline$<10$ & 3.90 & 3.12 & 2.68 & 2.85 & 3.69 & 3.41 & 3.27 \\
\hline $11-20$ & 3.86 & 3.10 & 2.78 & 3.11 & 3.63 & 3.32 & 3.30 \\
\hline $21-30$ & 3.56 & 3.05 & 2.57 & 3.03 & 3.82 & 3.35 & 3.23 \\
\hline$>30$ & 3.58 & 3.13 & 2.95 & 3.28 & 3.94 & 3.30 & 3.36 \\
\hline Average & 3.74 & 3.10 & 2.94 & 3.06 & 3.75 & 3.35 & \\
\hline
\end{tabular}

Source: Authors' calculation 
As expected, greater exhaustion after work is felt by employees in the older age categories (over 60 years of age, non-teaching staff, with secondary education and with more than 30 years of service). Employees are most dissatisfied with the reward system. In all the observed categories average marks are lower than 3 , and the lowest were among employees with a university degree, younger than 30 , non-teaching staff and those with 21-30 years of service.

\section{Conslusion}

The aim of this research conducted at the Faculty of Agriculture in Zemun was to determine the level of employee satisfaction, as well as the extent to which different factors affect their job satisfaction. In general, relatively satisfactory results were obtained. The average mark of job satisfaction, taking into account simultaneously all six extracted factors, is 3.32 . Men are more satisfied with work than women, as well as the teaching staff are more satisfied in comparison with the nonteaching staff. As for the age structure, the differences are minimal, and most satisfied employees are aged between 4150. Respondents with lower education levels are the least satisfied, while those with a PhD degree are the most satisfied. Regarding years of service, the least satisfied are employees with less than 10 years, while the most satisfied are those with more than 30 years of service. When directly asked "Taking all this into account, rate the satisfaction with the job performing" $\left(\mathrm{X}_{24}\right)$, employees ranked their overall satisfaction with the job with an average mark of 3.85.

The research results suggest directions of activity in order to increase employee satisfaction at the Faculty of Agriculture. Based on the responses of employees to an open question on the proposals for improving quality of work and employee satisfaction, it can be concluded that it is necessary to take actions which will improve the reward system, as well as create conditions for continuous improvement. Adequate measures for evaluating attitude toward work, work quality and execution of work duties can increase the motivation to work, but only if the rules are clear, and if there is a possibility to achieve a higher salary. As one of the most important motivational factors, salary is a source of relative dissatisfaction of employees. Although there has been a significant increase in salaries and regular payments in the last three years, one of the reasons for dissatisfaction is the fact that salary in Serbia, even when it is above average, is insufficient to meet the employees' needs. An important motivating factor that contributes to employee satisfaction is the possibility for career advancement. By improving teaching aids, equipment for scientific research, the availability of the latest literature and opportunities to monitor personal professional development., attending courses, symposiums, etc., employees are further motivated and this makes a significant contribution to increased workplace satisfaction.

Based on the results obtained through a questionnaire, it can be concluded that employees are working within an organization in which working conditions are good, but could be better, interpersonal relationships are correct, employees point out the need for personal affirmation and training, in order to progress at work, and thus contribute to the business improvement of the faculty.

The conclusions obtained in this study are very similar to the results of studies of researchers who have been dealing with this issue: the educational sector of any country has a unique importance particularly in knowledge creation. Competitiveness of this sector mostly depends on the satisfactory involvement and commitment of its employees, hence the perceived organizational practice and financial adequacy are the best predictor of job satisfaction (Leung et al., 2000). To attract and retain the talented, dynamic and competent, faculty and its performance management have become strategic human resource management (HRM) issue for universities (Chughtai, Zafar, 2006; Van den Brinketal., 2013). Klein (2007), studied the relationship between the demographic factors and job satisfaction. But he found no evidenc ethat supported any existence of such relationship. Literature shows that there is a considerable relationship between career advancement opportunities and job satisfaction (Peterson et al., 2003) and that there is a significant relationship between pay and job satisfaction (Khalid et al.; 2012; Kusku,2003). Luthans(2005), suggested that pay, promotion, work, supervision and fellow workers are the main determinants of job satisfaction. People who were satisfied at work had support from colleagues. Bozeman and Gaughan (2011) found that faculty employees are more satisfied with their jobs when they see that they are paid what they are worth and when they perceive that their colleagues respect their research work. The management of the faculty should give considerable emphasis on performance appraisal and periodically performance appraisal should be conducted. Promotion, incentives, recognition and appreciation should be performance based. Secondly, compensations are significant and prominent determinants of academic professionals' job satisfaction. Competitive salary packages, periodic increment, and additional benefits leverage academic professional's job satisfaction (Vila and García-Mora, 2005).

\section{Acknowledgements}

This work was supported by the Ministry of Science and Technological Development: "Development and application of new and traditional technologies in the production of competitive food products with added value for domestic and world markets- Create wealth from the wealth of Serbia" and "Rural Labour Market and Rural Economy of Serbia - Income Diversification as a Toll to Overcome Rural Poverty". 


\section{REFERENCES}

[1] Bartlett, M. S. (1954): A note on the multiplying factors for various chi square approximations. Journal of Royal Statistical Society, 16 (Series B), p. 296-298.

[2] Bozeman, B. and Gaughan, M. (2011). Job satisfaction among university faculty: Individual, work, and institutional determinants. Journal of Higher Education. 82(2): 154-186.

[3] Chen,S.-H., Yang,C.-C.,Shiau,J.-Y.,\&Wang,H.-H. (2006). The development of an employee satisfaction model for higher education. The TQM Magazine,18 (5),484-500.

[4] Chughtai,A. A.,\&Zafar,S.(2006). Antecedents and Consequences of Organizational Commitment Among Pakistani UniversityTeachers.Applied H. R.M. Research, 11(1),39-64.

[5] Davis, R.V. (1992): Job satisfacion. In: Jones LK (ed.) Encyclopaedia of career change and work issues (PP. 142-143); Phoenix, The Oryx press.

[6] Dessler, G. (2007): Fundamentals of human resource management; 4th Edition, Data status, Belgrade.

[7] Edwards, N., Kornacki, J., Silversin, J. (2002): Unhappy doctors: What are the causes and What can be done? BMJ; 324: 835-842.

[8] Faragher, E.Bb, Cass, M., Cooper,CL. (2005): The relationship between job satisfaction and health: a meta analysis; Occupational and Enviromental Medicine, 62:105-112.

[9] Field, J., (2008): Job Satisfaction Model for retention, weblog, viewed on March 7th 2015, http://talentedapps.wordpress.com/2008/04/11/job-satisfaction-model-for-retention/

[10] Furnham,A.(1997):ThePsychologyofBehavioratWork,Thelndividualintheorganization,Osychology Press,p. 718.

[11] IBM SPSS statistics 20. Faculty of agriculture, Belgrade, Serbia.

[12] Kaiser, H. F. (1974): An index of factorial simplicity. Psychometrica, 39, 31-36.

[13] Khalid,S.,Irshad,M.Z.,\&Mahmood,B.(2012).Job Satisfaction among Academic Staff: A Comparative Analysis between Public and Private Sector Universities of Punjab, Pakistan. International Journal of Business and Management 7(1). doi:10.5539/ijbm.v7n1p126

[14] Klein, J. (2007). The relationship between job satisfaction and leadership practices : a survey-based analysis of full time business faculty Wisconsin technical college system. Capella University. Minneapolis, MN: Unpublished PhD dissertation

[15] Kusuku,F.(2003).Employee satisfaction in higher education: the case of academic and administrative staff in Turkey. Career Development Inernational Journal,8(7), 347356.http://dx.doi.org/10.1108/13620430310505304

[16] Leung, T.-w., Siu,O.-I.,\&Spector, P.E.(2000). Faculty Stressors, JobSatisfaction, and Psychological Distress Among University Teachers in Hong Kong; The Role of Locus of Control. International Journal of Stress Management, 7(2), 121-138.

[17] Luthans,F.(2005).Organizational behavior, McGraw-Hills.

[18] Locke E.A. (1976): The nature and causes of job satisfaction. In: Dunnete MD (ed.) Handbook of industrial and organizational psychology; Chicago: Rand McNally; p.1319-1328.

[19] Maslow A. (2004): Psychology of management, Adizes, Novi Sad.

[20] Mcbridea,S.A.,Mundayb,R.G.,\&Tunnellb,J.(2006). Community College Faculty Job Satisfaction And Propensity To Leave. Community Junior College Research Quarterly of Research and Practice, 16(2), 157-165. Doi:10.1080/0361697920160204

[21] Mihailović D. (2002): Organizational psychology, Faculty of Organizational Sciences, Beograd.

[22] Oshagbemi, T.(1997). Jobs at is faction profiles of university teachers. Journal of Managerial Psychology,12(1), 27-39.http://dx.doi.org/10.1108/02683949710164235

[23] Oshagbemi, T. (2003). Personal correlates of job satisfaction: empirical evidence from UK universities. International Journal of Social Economics,30(12),12101232.http://dx.doi.org/10.1108/03068290310500634

[24] Peterson, D. K., Puia, G. M., \& Suess, F. R. (2003). An exploration of job satisfaction and commitment among workers in Mexico. Journal of Leadership and Organizational Studies,10(2),7388.http://dx.doi.org/10.1177/107179190301000208

[25] Prvulović S., Šekularac I., Živković Ž. (2009): Employee motivation as a factor of the business success.Business policy, 38(1-2), p. 54-65.

[26] Rani, T. Kamalanabhan, M. Selvarani (2011): Work/life balance reflections on employee satisfaction. Serbian Journal of Management, 6(1), p. 85-96.

[27] Shahzad,K.,Mumtaz,H.,Hayat,K.,\&Khan,M.A.(2010). Faculty Workload, Compensation Management and Academic Quality in Higher Education of Pakistan: Mediating Role of Job Satisfaction. European Journal of Economics, Finance and Administrative Sciences, 111-120. 
[28] Sousa-Poza A. (2000): Well-being at work: a crosssectional study of the levels and determinants of job satisfaction; Journal of Socio-Economics; 29:517-538.

[29] Sseganga, K., \& Garrett, R. M. (2005). Job satisfaction of university academics: Perspectives from Uganda. Higher Education, 50,33-56.http://dx.doi.org/10.1007/s10734-004-6346-0

[30] Tabachnick, B. G., \&Fidell, L. S. (2007). Using multivariate statistics (5th ed.), Boston: Allyn and Bacon.

[31] VandenBrink,M.,Fruytier,B.,\&Thunnissen,M.(2013). Talent management in academia: performance systems and HRM policies. Human Resource ManagementJ ournal, 23(2), 180-195.

[32] Vila,L. E.,\&García-Mora, B.(2005). Education and the Determinants of Job Satisfaction. Education Economics, 13(4), 409-425. doi:10.1080/09645290500251730

[33] Viswesvaran,C.,Deshpande,S.P.,\&Joseph,J.(1998).Job satisfaction as a function of top management support for ethical behavior. Journal of Business Ethics, 17(4), 365371.http://dx.doi.org/10.1023/A:1017956516324

[34] Ward, M. E., \&Sloane,P. J. (2000). Non-pecuniary Advantages Versus Pecuniary Disadvantages; Job Satisfaction Among Male And Female Academics In Scottish Universities. Scottish Journal of Political Economy, 47(3), 273-303. doi:10.1111/1467-9485

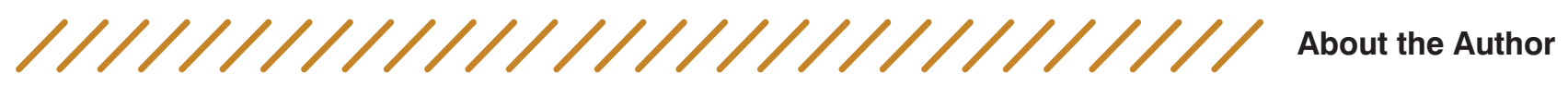

Blaženka Popović: University of Belgrade, Faculty of Agriculture, Zemun

Associate Professor at the Department of Agricultural Economics, Faculty of Agriculture, University of Belgrade, Belgrade, Serbia, (main subjects: Resource management in agricultural enterprises, Management of occupational health and safety in agriculture, SMEs in agribusiness, Environmental management in agriculture, Planning in agribusiness).

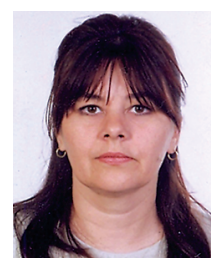

Radojka Maletić:

University of Belgrade, Faculty of Agriculture, Zemun

Full Professor at the Department of Agricultural Economics, Faculty of Agriculture, University of Belgrade, Belgrade, Serbia, (main subjects: Statistic, Statistical Quality

Control).Her scientific activity is reflected in the area of statistical theory and the applications of statistical methods in biotechnology, agricultural economy and medicine.

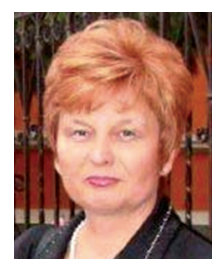

Tamara Paunović: University of Belgrade, Faculty of Agriculture, Zemun

Teaching Assistant at the Department of Agricultural Economics, Faculty of Agriculture, University of Belgrade, Belgrade, Serbia, (main subjects: Farm Management, Management of agricultural extension service and Planning in agribusiness).

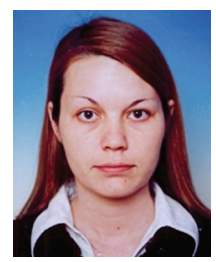

